\title{
First Observation of Hemoglobin M Saskatoon (ß63 (E7) His>Tyr(C-T)) in the Iraqi Population
}

\author{
Iraklı Bir Hastada İlk Kez Gözlenen Hemoglobin M Saskatoon \\ ( 363 (E7) His $>$ Tyr $(C-T)$ )
}

\author{
Nejat Akarl, Çiğdem Arslan' ${ }^{1}$ Emin Kürekçi ${ }^{2}$ \\ ${ }^{1}$ Ankara University, School of Medicine, Pediatric Genetics Department, Ankara, Turkey \\ ${ }^{2}$ Gülhane Military Medical Academy, Department of Pediatric Hematology, Ankara, Turkey
}

\section{To the Editor,}

Hemoglobin M Saskatoon ( $\$ 63$ His>Tyr(C-T)) is a rare hemoglobin variant that was first reported in Japan, followed by the US, Indonesia, Algeria, Russia, India, and Germany [1-8]. It was also reported in combination with another variant-Hb Hamilton [9]; however, it has yet to reported in the Turkish population $[10,11]$. The present report describes the first observation of this variant in an 9 -year-old Iraqi boy that presented with fatigue and greyblue discoloration of the distal extremities and mucous membranes since birth. Physical examination showed cyanosis and clubbing of the fingers and toes. Complete blood count, reticulocyte count, liver and renal function tests, and abdominal ultrasound were normal. Echocardiography and angiography showed no abnormality. Blood gas analysis showed an $\mathrm{O}_{2}$ saturation of $91 \%$ and a methemoglobin level of $24.5 \%$. Capillary hemoglobin electrophoresis showed hemoglobin M (Iwate or Saskatoon). Family history was unremarkable.

PCR amplification of the b-globin gene was performed using primers F:5'-GGTTGGCCAATCTACT CCCA GGAG-3' and R:5'-GCTCACTCAGTGTGGCAAAG-3' for exons 1 to exon 2. For exon 3 PCR amplification was performed first using the primers F:5'-CAATGTATC ATGCCTCTTT GCACC-3' and R:5'-GAGTCAAGGCTGAGAGATACAGGA-3' for a 861-bp fragment, and then using the primers 5'-TGCATATAAATTGTAACTGAT-3' and 5'-CACTGACCTCCCACA TTCCC-3' for nested amplification. Direct automated sequencing of all amplified regions of the b-globin gene was performed using an automatic sequencer (Beckmann Coulter, USA). Two different sets of PCR reactions with forward and reverse amplification were performed.

The second exon amplification showed that the variant was a missense mutation at codon 63 coding for $C$ to $T$ transition that leads to histidine substitution by thyrosine, which was previously described as $\mathrm{Hb}$ M Saskatoon (Figure 1).

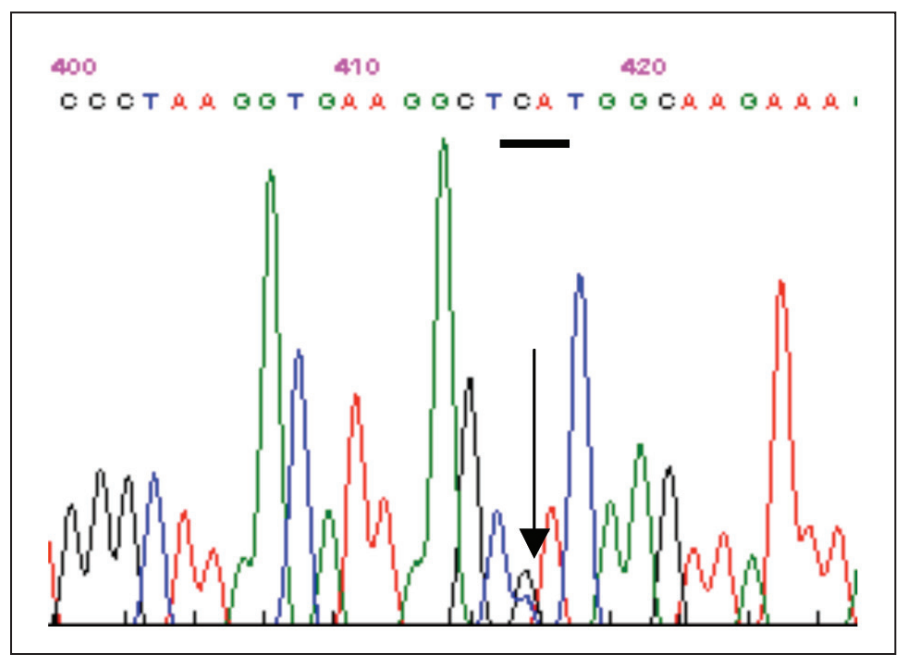

Figure 1: The patient's sequencing data showing Hb M Saskatoon. 
There are several hemoglobin variants that cause cyanosis, of which $\mathrm{Hb} \mathrm{M}$ Iwate was reported previously in the Turkish population $[1,10,12]$. This is the first observation of $\mathrm{Hb} \mathrm{M}$ Saskatoon in an Iraqi Turkish boy. The clubbing of fingers in the propositus is an unusual finding, as patients with $\mathrm{Hb} \mathrm{M}$ do not have clubbing. Despite thorough investigation, including cardiovascular procedures, we could not determine the cause of clubbing; however, Mast et al. reported 3 brothers with congenital recessive methemoglobinemia due to homozygous NADH diaphorase deficiency [13]. One of the probands had marked digital clubbing, also an unusual feature of that disease. Although HbM Saskatoon is primarily a non-hazardous disease, as $\mathrm{HbM}$ is susceptible to oxidative stress it is advisable to avoid oxidative drugs.

\section{Conflict of Interest Statement}

None of the authors has any conflicts of interest, including specific financial interests, relationships, and/or affiliations, relevant to the subject matter or materials included.

\section{References}

1. Huismann THJ, Carver MFH, Efremov GDA. Syllabus of hemoglobin variants. The Sickle Cell Anemia Foundation. 2nd ed. GA, USA: Augusta, 1998

2. Vella F, Kamuzora H, Lehmann H, Duncan B, Harold W. A second family with hemoglobin M Saskatoon in Saskatchewan. Clin Biochem 1974; 7 (2): 186-191

3. Nagai M, Yoneyama Y. Reduction of methemoglobins M Hyde Park, M Saskatoon and M Milwaukee by ferredoxin and ferredoxin-nicotinamide adenine dinucleotide phosphate reductase system. J Biol Chem 1983; 258 (23): 14379-14384
4. Arbane-Dahmane $\mathrm{M}$, Rouabhi $\mathrm{F}$, Hocine $\mathrm{M}$, Benabadji M, Redad M, Blouquit Y, Arous N, Delanoe-Garin J, Riou J, Lacombe C. Hemoglobin M Saskatoon (alpha 2 beta 2 63(E7) His----Tyr) in an Algerian family. Hemoglobin 1985; 9 (5): 509-511

5. Waye JS, Patterson M, Eng B. De novo beta-globin gene mutation [beta 63(E7)His-->Tyr] giving rise to Hb M disease in a Newfoundlander. Hemoglobin 1994; 18 (6): 441-443

6. Suryantoro P, Takeshima Y, Haryanto A, Matsuo M. C to $\mathrm{T}$ transition at the first nucleotide of codon 63 of the betaglobin gene corresponding to hemoglobin M-Saskatoon in an Indonesian boy. Jpn J Hum Genet 1995; 40 (2): 195-201

7. Hütten $\mathrm{M}$, Kohne $\mathrm{E}$, Yagmur $\mathrm{E}$, Schaible $\mathrm{T}$, Wenzl $\mathrm{T}$, Wagner N, Heimann K. Persistent cyanosis in a 4 month old infant with severe pneumonia and haemoglobin M. Klin Padiatr 2009; 221 (5): 305-307

8. Kedar PS, Nadkarni AH, Phanasgoankar S, Madkaikar M, Ghosh K, Gorakshakar AC, Colah RB, Mohanty D. Congenital methemoglobinemia caused by $\mathrm{Hb}-\mathrm{M}_{\text {Ratnagir }}$ $(\beta-63$ CAT $\rightarrow$ TAT, His $\rightarrow$ Tyr $)$ in an Indian family. Am J Hematol 2005; 79 (2): 168-170

9. Brunner-Agten S, Hergersberg M, Herklotz R, Hirt A, Huber AR. Compound heterozygosity of Hb Hamilton and de novo mutated HbM Saskatoon. Ann Hematol 2010; 89 (5): 517 518

10. Altay Ç. Abnormal Hemoglobins in Turkey. Turk J Haematol 2002; 19: 63-74

11. Akar E, Akar N. A review of abnormal hemoglobins in Turkey. Turk J Hematol 2007: 24; 2-3

12. Özsoylu Ş. Congenital methemeoglobinemia due to hemoglobin M. Acta Haematol 1972; 47: 225-232

13. Mast A, Milo R, Junien C, Leroux A, Krishnamoorthy R, Wajcman H, Labie D, Kaplan JC. Congenital enzymopenic methaemoglobinaemia. Clinical and biochemical study of a family with three homozygotes. Acta Haematol 1976; 56 (3): 174-182 